\title{
Experience of Philosophical Reflection about Problems of the Technosphere Safety (Based on the Material of Soviet and Russian Philosophical Discussions)
}

\author{
Makuhin Petr Gennadyevich, Ph.D., \\ Associate Professor, Philosophy and Social Communications faculty, \\ Omsk State Technical University
}

\begin{abstract}
The article continues to implement a philosophical reflection on the technosphere, considered as a necessary part of the noosphere, in the aspect of technosphere disasters, whose "Sword of Damocles" "hangs" over humanity on an increasingly "thin" "horsehair". However, from our point of view, they basically will always be solvable, and we consider the cultivation of "university", "multifaceted", "multidisciplinary" type of education to be the "key" to their solution (in contrast to "mosaic", "highly specialized", "limited professional" education). Indeed, it is "one-dimensional people", "narrow specialists" = "learned ignoramuses", "Das MAN" (in the terminology, respectively, H. Marcuse, J. Ortega y Gasset and M. Heidegger) act, firstly, as a brake of technosphere progress, and, secondly and most importantly, the "creator" of technosphere disasters.

Key words: technosphere, technosphere disasters, "university" and "mosaic" education, science-based and spontaneous development of the technosphere.

Introduction. At the end of the second decade of the 21 st century, "shaken" by the disasters of the technosphere, it does not seem necessary to justify the relevance of philosophical understanding of the ways of its safe development. Also, the reader, we hope, will not have a question, why is such a reflection relevant to be based exactly on the material of the Russian debates: in the first article in the same issue of the "IntellectualArchive", we tried to show the heuristic nature of that version of philosophical reflection on technology, in which the technosphere is considered as a necessary part of the noosphere. And comprehension of the latter as, we repeat, a regular stage in the evolution of the biosphere from the 19th century was carried out by the "Russian cosmists". But we realize that the question is legitimate: why did we focus on discussions about education, in particular in terms of its "breadth", "multifacetedness", "multidisciplinarity"? Indeed, it would seem, on the contrary, it is precisely the "narrow", but "deep" professional training of future technical specialists that can prevent the technosphere disasters of the future!
\end{abstract}

1. Our position in the "technicalism - anti-technicalism" coordinate system. 
We must say right away that we will not consider the position of anti-technicalism, i.e., technical pessimism, declaring - according to authoritative Russian "Humanitarian Encyclopedia" - the technology "and scientific and technical knowledge in general ... a negative alternative to social and cultural values, and scientific and technological achievements are rejected as possible tools for enslaving a person" [1, p. 7]. The brightest representatives of this position, if listed in chronological order, are J.-J. Rousseau, K.Jaspers, M. Heidegger, "Frankfurt School", J. Ellul, and others. The last in his work "Technique" (1962), acknowledged that the latter "became the fate of mankind", and in a work with the significant title "Technological bluff" (1988) claims that this does not lead to any particular technical disasters (even such large-scale, like Chernobyl, Fukushima, etc.), and to the catastrophe of humanity as such. This creates a "philosophical absurdity without a way out", "which has turned into a kind of ontology of the world formed by technology" [2, p. 284]. The discussion with this position is beyond the scope of this article, but we also do not accept the opposite extreme - technicalism, that is, technical optimism dating back to the Renaissance philosophy, which "was inclined to see in technology and scientific and technological progress (scientific and technological progress - P. M.) the most important means of resolving social problems and achieving the common good "[3, p. 525]. Subsequently, this position is being developed by the following thinkers: E. Kapp, T.Veblen, J. Galbraith, W. Rostow, D. Bell, A. Toffler, P.K. Engelmeyer and others.

Trying to get between these "Scylla and Charybdis", we say that although we do not believe that civilization, which has embarked on the path of technological progress, has necessarily doomed itself to death from technological disasters, at the same time we do not agree that the indicated progress "in itself" in the future is capable of ridding mankind of catastrophes, both technogenic and social. The threat of these catastrophes will always remain (and moreover, as we show later, intensify), but at the same time they basically will always be solvable, and we consider cultivation of the "multi-faceted", "multidisciplinary" education the "key" to their solution.

\section{The universality of the experience of Russian debates regarding educational} reforms. In our opinion, contemporary Russian discussions on the problems of education are of interest to foreign experts in the field of educational philosophy, and primarily because the Russian Federation has undergone a dramatic change in the types of education 
over the past three decades (we'll clarify: in the part of the latter that is accessible to all population). Namely: the "university" type is replaced by the "mosaic", "highly specialized", "limited professional" type of education. Here is a concise description of their differences, given by one of the most influential modern Russian philosophers, S. G. KaraMurza. The "university" school (in the broad sense of the term) "based on the Christian tradition, emerging from the monastery and the university, sets the task of " educating the individual "- a person who turns to God (more broadly, to the ideals)" [4, p. 247]. Accordingly, from the very first steps an "integral set of principles of being" was given, i.e. knowledge immediately connected to the system. For bourgeois society, "a manipulated person of the mass, formed in a mosaic culture" became necessary. [4, p. 247]. (Which, of course, does not negate the importance of university education for the economic and political elite). We find a similar contrast in other prominent Russian thinkers, for example, V. A. Kanke, who distinguishes education as mastering only "those skills that are needed directly at the future workplace. Nothing superfluous, only the most necessary "[5, p. 240] from education, interpreted as "the most effective inclusion of a person in the culture of mankind" [5, p. 240]. With such a campaign, the meaning of even professional training lies in "a comprehensive cultivation of such values as truth, goodness, beauty, creativity, responsibility" [5, p. 240]. Under the conditions of a "step-by-step" (continuing, we repeat, almost three decades) change of this approach to education to a "highly specialized" one, the theoretical, and firstly philosophical, apology of the "university" type of education, is especially relevant for Russian authors. And the relevant arguments they developed seem to be of interest outside Russia too. (Here, readers may ask us in surprise: where is the consideration of the arguments of the opposite side?! We are aware that this may seem biased, but still say: we are not aware of any philosophical arguments proper, i.e. The "opposite side" does not operate with scientific arguments, but administrative, policy documents).

\section{3. "Learned ignoramuses" as the "creators" of technosphere disasters.}

Returning to the question of the safe development of the technosphere, let us cite the idea of the most authoritative Russian philosopher of recent decades, V. S. Styopin, regarding the radical difference between the so-called "traditionalist" and so called "technogenic" types of civilizations. The most important basis for the vital activity of the last of these types is the 
development of engineering and technology, "not only through spontaneous flowing innovations in the sphere of production itself, but also through the generation of new scientific knowledge and its introduction into technical and technological processes" [6, p. 84], which cannot but cause fundamental social changes. So that this does not seem trivial, we cite V. S. Styopin's conclusion that "technogenic civilization opens up new risk zones" [6, p. 98]. Not being able to consider in detail the ideas of M. Heidegger, K. Jaspers, J.Ortega y Gasset, representatives of the "Frankfurt School", N.F. Fedorov and other "Russian cosmists" (among which we particularly highlight the "late" N. Y. Berdyaev) and other thinkers, "classics", who have penetratingly analyzed such "risk zones", we restrict ourselves to the following laconic reasoning by modern Russian authors. (Immediately making a reservation that we are certainly in solidarity with their critical attitude to the trend of Russian education reforms they analyze). A.F. Polomoshnov in first place among the problems of the "balance of the general orientation or the goals of education" [7, p. 69] puts the following: "a balance of focus on the development of a widely and deeply educated personality with an integral comprehensive fundamental worldview or on the development of high professionalism in a narrow specialized field" [7, p. 69]. Similarly, O.D.Machkarina writes that "the image of a modern student focused on narrow specialization, accompanied by a departure from fundamentality in educational strategy, a drop in the level of general education and the degradation of society, a crisis of education in general," relates to the following: " avalanche-like increase in information and the need for its assimilation " $[8, \mathrm{p}$. 22] to turn a student into a specialist. I. V. Fotieva and T. A. Artamonova detail this idea in this way: "First, the growing volume of scientific knowledge and the specialization of sciences, as claimed, raise the question of the inevitability of a narrow specialization of graduates. Secondly, fundamental education leads to student overload. And the last argument is the demand of the market, that is, the need to raise only those specialists whom society demands "[9, p. 153].

Now we will consider the tendency brightly "highlighted" by these authors in the context of the prospects for disasters in the technosphere. As S. I. and N. A. Nekrasov write (whose ideas we have already referred to in another article in this journal), "the spontaneous development of the technosphere threatens the safe existence of human being. In this regard, in the future, scientifically-based development of the technosphere as an 
integral part of harmonious noosphere "[10, p. 209]. N. V. Popkova also speaks of the same thing: "of all the proposed options (the future - M. P.), the most probable is the further development of technosphere growth trends, with the goal of forming technogenic complexes ... a unified and people-controlled technosphere system on the planet instead of a kaleidoscope" [11, p. 136]. (Here, however, one can doubt that such an - optimistic version of the future is "most probable"). The following thought of S. I. and N. A. Nekrasov is especially important for us: such a "scientifically-based development" of the technosphere "will cause a significant increase in the number of objects of technical creativity" [10, p. 209].

Summing up this semantic block, we put forward the following thesis. The "Sword of Damocles" of the spontaneous development of the technosphere, which threatens the very existence of mankind, requires representatives of an increasing number of specialities, primarily technical ones, to "not lock themselves" in their professional frameworks, that is, not to be "narrow specialists." Indeed, firstly, the increasing complexity of the technosphere, in which "the number of objects of technical creativity" increases, requires many even working specialities - not to mention engineering! - both knowledge in related fields, and those thinking skills that can be formed only when studying a wide range of subjects, which necessarily includes a social and humanitarian component. Secondly, let us point out the danger of the fact that "narrow specialists" will not be able to timely notice and prevent catastrophic technosphere processes. (In other words, they cannot contribute to the science-based development of the technosphere as opposed to the spontaneous). Moreover, they themselves can provoke them, in connection with which it is necessary to recall the warning of J. Ortega y Gasset about the danger associated with the appearance in the 20th century. "knowledgeable ignoramuses." If before this century "people were simply divided into knowledgeable and ignorant" [12, p. 101], then in modern times a type of narrow specialists who cannot be ranked in any of the indicated categories has arisen. For our topic, it is especially important to take into account the threat to the technosphere lurking in the "internal conflict" of these "one-sided specialists", each of whom "will approach any field which he does not understand, not as an ignoramus, but with the bold arrogance of a person who knows his own worth" [12, p. 101]. It turns out that the "learned ignoramus" - as a product of education aimed at a narrow specialization - poses a much 
greater danger to the technosphere, and, consequently, society, rather than a completely uneducated, ignorant person. Indeed, the latter, in a situation in which he is incompetent, will not be allowed to draw unreasonable conclusions by common sense, which is blocked by "one-sided specialists" because of their self-conceit.

Conclusion. We summarize everything considered by putting the reader "in front" of the choice: either the education system will reproduce "technogenic man" of "mass society" ("one-dimensional man", "narrow specialist" = "learned ignoramus", "Das MAN" in the terminology, respectively, H. Marcuse, J. Ortega y Gasset and M. Heidegger), thereby increasing the likelihood of death of both the most technogenic civilization and humanity in whole. Or the educational system will contribute to the formation of comprehensively developed, harmonious personalities, reducing the likelihood and scale of disasters in the technosphere.

\section{References}

1. L. G. Titarenko, E. M. Babosov, V. S. Bernstein Antitekhnitsizm // Gumanitarnaia entsiklopediia: Kontsepty (Elektronnyi resurs) [Antitechnicism // Humanitarian Encyclopedia: Concepts (Electronic resource)]. Center for Humanitarian Technologies, 2002-2019 (latest revision: 04/23/2019). URL: https://gtmarket.ru/concepts/7235

2. J. Ellul Tekhnologicheskii blef [Technological bluff] // This is a man: Anthology / Compilation, introductory article: P. S. Gurevich. M.: High School, 1995. P. 265-284.

3. V.T. Grafsky Tekhnitsizm i antitekhnitsizm [Technicalism and anti-technicalism] // Sociological dictionary / resp. ed. G.V. Osipov, L.N. Moskvichev. M.: Norma, 2008 P. 524525 .

4. S. G. Kara-Murza Manipuliatsiia soznaniem [Manipulation of consciousness.] M :: Publishing House: Eksmo, 2005. p.832

5. V. A. Kanke Filosofiia: Uchebnoe posobie dlia studentov vysshikh $i$ srednikh spetsial'nykh uchebnykh zavedenii [Philosophy: Textbook for students of higher and secondary specialized educational institutions.] M.: Logos, 2001. p.272

6. V.S. Styopin Tsivilizatsiia i kul'tura [Civilization and Culture.] SPb .: SPbGUP, 2011. p. 408

7. A.F. Polomoshnov Defundamentalizatsiia rossiiskogo obrazovaniia [Defundamentalization of Russian education] // Bulletin of the Don State Agrarian University. 2016. No. 3-2 (21). P. 69-83.

8. O. D. Machkarina Byt' li filosofii v vuze? $K$ voprosu o soderzhanii sovremennogo 
obrazovaniia [Is there a philosophy at a university? On the content of modern education] // Bulletin of St. Petersburg University. Series 6 Political Science. International relations 2014. No. 2. No. 3. pp. 22-30.

9. I.V. Fotieva, T.A. Artamonova Defundamentalizatsiia obrazovaniia: tendentsii $i$ otsenki // Aktual'nye problemy sovremennoi nauki v 21 veke [Defundationalization of education: trends and assessments // Actual problems of modern science in the 21st century]: collection of articles. Mater. 3rd international scientificpractice. Conf., Part 1 (Makhachkala, December 28, 2013). Makhachkala: LLC “Approbation”, 2013. P.153-154.

10. S.I. Nekrasov, N.A Nekrasova. Tekhnosfera // Filosofiia nauki i tekhniki: tematicheskii slovar' spravochnik [Technosphere // Philosophy of Science and Technology: Thematic Reference Dictionary]. Orel: OSU, 2010. P. 208-209.

11. N.V. Popkova Osnovnoe protivorechie tekhnosfery // Filosofiia i obshchestvo [The main contradiction of the technosphere // Philosophy and Society.] 2005. 3.40 P. 121-136.

12. J. Ortega y Gasset Vosstanie mass [Rise of the masses] // J. Ortega y Gasset Rise of the masses ... M .: AST: ST MOSCOW, 2008. - P. 13. 